\title{
Albian Stage and Substage boundaries
}

\author{
H. G. OWEN
}

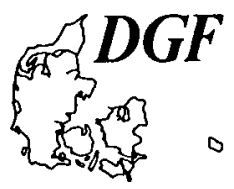

\begin{abstract}
Owen, H. G.: Albian Stage and Substage boundaries. Bull. geol. Soc. Denmark, vol. 33 pp. 183-189, Copenhagen, September, 11th, 1984. https://doi.org/10.37570/bgsd-1984-33-16

The base of the Albian Stage has been defined in the European province at the earliest appearance of the ammonite Leymeriella ('Proleymeriella') schrammeni anterior Brinkmann, the earliest member of the important 'mid-Cretaceous' ammonite superfamily Acanthocerataceae. A type section in the Harz foredeep region of northern Germany has been proposed. A certain amount of intra-provincial variation in the ammonite fauna around this boundary is known in the European province. This does not provide insuperable difficulties, however, in the recognition of late Aptian and early Albian ages in the various lithological sequences within this province. Leymeriella is generally unknown in the Canadian-Russian Arctic province, but the association of a Leymeriella of schrammeni Subzone age with a Freboldiceras in north Greenland, provides a useful correlation of these largely disparate provincial ammonite faunas. Correlation with the Gondwanan province is less certain at present. The length of Albian time (14-15.5 $\mathrm{Ma}$ ) has led to the recommendation that Substage boundaries should be defined for the Middle and Upper Albian. The Subzone of Lyelliceras lyelli provides a good base for the Middle Albian, one that can be recognized in both the European and Gondwanan provinces. The base of the Upper Albian is marked by Dipoloceras cristatum an ammonite which is also of widespread occurrence in both of these provinces. The occurrence of the Arctic province ammonite Pseudogastroplites in the cristatum Subzone provides a good marker for correlation of this province with the European and Gondwanan provinces.
\end{abstract}

H. G. Owen, Department of Palaeontology, British Museum (Natural History), Cromwell Road, London SW7 SBD, UK, February 3rd, 1984.

The Albian Stage is characterised by three distinct ammonite faunal provinces; the European, Arctic and Gondwanan. The stratigraphy and ammonite sequence of the European province has been studied in detail (eg. Spath 1923-43, Breistroffer 1947, Casey 1961 \& 1960-, Destombes 1979, Owen 1971, 1976, 1984, Saveliev $1974,1976,1981)$ and the so-called 'standard' ammonite zonal and subzonal scheme for the Albian applies, essentially, to that region alone. The Arctic province had an ammonite fauna endemic to it which is largely disparate to both the European province and the North Pacific subprovince of the Gondwanan province. A separate zonation has been developed for this Arctic province (eg. Imlay 1959, 1960, Jones \& Grantz 1967, Jeletzky 1980), and the few points of correlation with the European province have been discussed by Birkelund \& Håkansson (1983), Jeletzky (eg. 1980) and Owen (1973).

The Gondwanan province includes all the geographic regions of the Earth not included in the European and Arctic provinces. Invasions of ammonites characteristic of the Gondwanan province into the European province occurred throughout the Albian. In the Upper Albian, the more cosmopolitan elements co-existed with the endemic hoplitinids in the European province. Points of correlation are relatively frequent, therefore, within the late Lower, Middle and Upper Albian between these two provinces. Unfortunately, there appears to be a widespread sedimentary hiatus in the epicontinental seas of the Gondwanan province involving the late Aptian (Hypacanthoplites jacobi Zone) and the early Albian (the equivalent of the Leymeriella tardefurcata Zone). There are problems, therefore, in the recognition of the base of the Stage on a global scale; problems which not only affect the ammonite faunas, but the ostracod and foraminferal faunas and the nannoplankton as well.

The length of the Albian in terms of 'absolute' isotope dating (14-15.5 Ma. eg. Odin 1982, Harland et al. 1982), makes it advisable to recognize and define Substage boundaries for the Middle and Upper Albian. The definition of these two additional boundaries provides index ammonites (Lyelliceras lyelli and Dipoloceras cristatum respectively) which are geographically widespread in the epicontinental sea deposits of both the Gondwanan and European provinces. It is possible to correlate these short intervals with the 


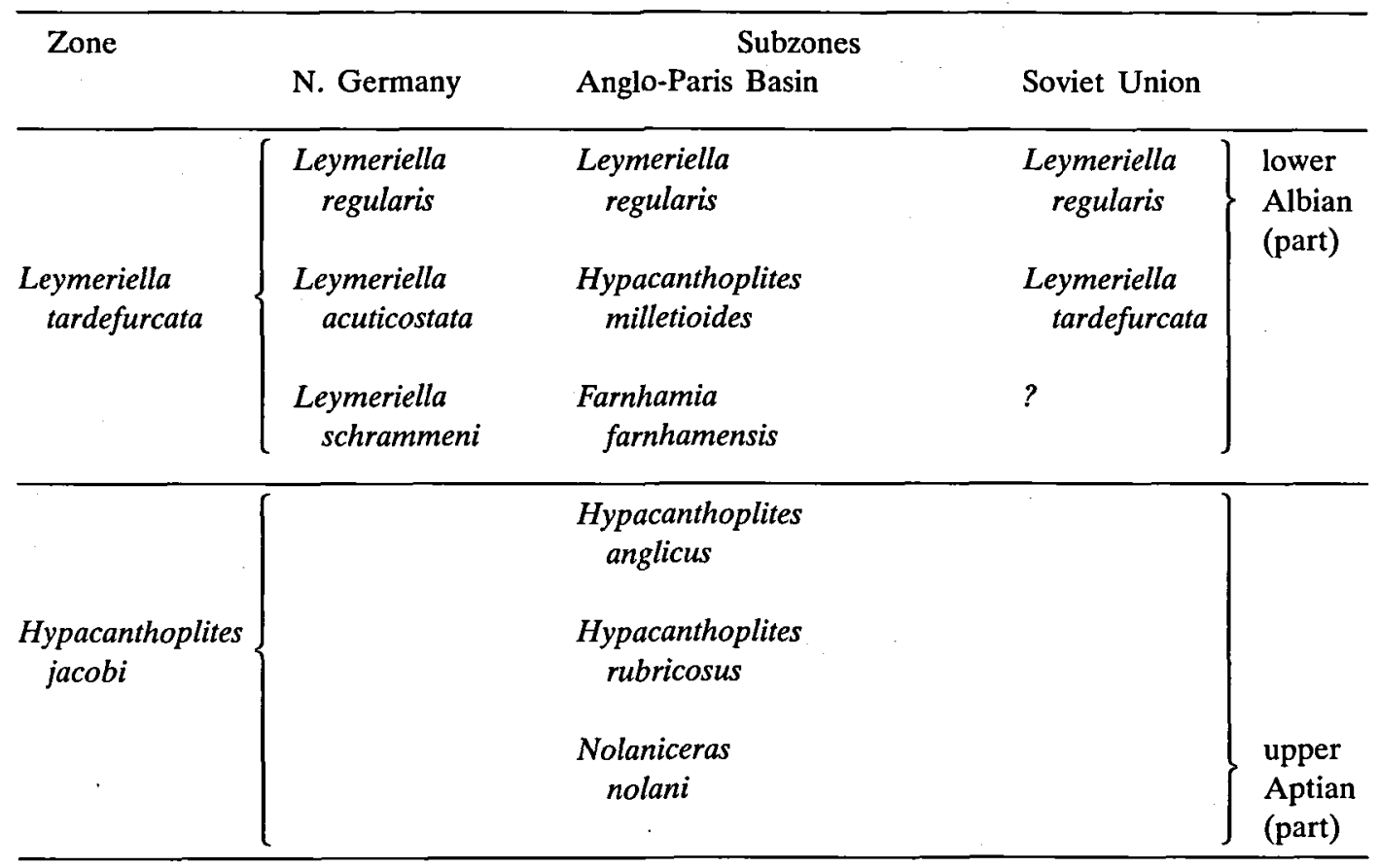

Table 1. Lower boundary of the Albian in the European province according to the ammonite zonation.

Arctic faunal province. Apart from the distribution of ammonites, micropalaeontological markers are also available at these Substage boundaries which are of use in the classification of oceanic borehole core sequences in which ammonites are absent or very uncommon.

\section{The base of the Albian Stage}

Breistroffer (1947) recommended that the base of the Albian Stage should be placed at the beginning of the Leymeriella tardefurcata Zone. Hitherto, Spath (eg. 1943, 668) had included in the Albian his Zone of Diadochoceras nodosocostatum which occurred immediately before the Zone of Leymeriella tardefurcata. According to Spath, the nodosocostatum Zone is characterized by species of what are now called Nolaniceras in the early part of the Zone (nolani Subzone) and Hypacanthoplites (jacobi Subzone) in the later part; ammonites of strong Aptian affinities. Casey (eg. 1957, 1961) followed Breistroffer in placing the base of the Albian Stage at the begin- ning of the tardefurcata Zone (base of the Leymeriella schrammeni Subzone), and this practice has been generally followed. The base of the schrammeni Subzone, and of the Albian Stage in the European faunal province, is marked by the appearance of Leymeriella schrammeni anterior Brinkmann, the first member of the genus Leymeriella which proliferated within the tardefurcata Zone and gave rise to the important superfamily Acanthocerataceae (eg. Brinkmann 1937, Casey 1957, Kemper 1975, Saveliev 1973).

The author has recommended that a horizon, the junction of Beds $6 a$ and $6 \mathrm{~b}$ in a measured section of clays spanning the uppermost Aptian and lowest Albian exposed near Vörhum in the Hannover-Braunschweig area of north Germany, be taken as a formal boundary stratotype (Owen 1979, 569). This lithological boundary and its palaeontology in north Germany has been described in some detail (Kemper et al. 1982a).

Within many areas of the European faunal province, the earliest Lower Albian is either not represented by sediment sequences, or is subject to minor but important ammonite provincialism (table 1). Leymeriella appears to have been en- 
demic initially to the Albian North Sea basin, the margins of which included North Germany and eastern Greenland, with a narrow strait linking the Arctic epicontinental seas marked by Spitzbergen and north Greenland (Nagy 1970, Owen 1973, Birkelund \& Håkansson 1983). Although Leymeriella extended to areas of eastern and southern Europe by the early Leymeriella acuticostata Subzone (Owen 1984), it did not become ubiquitous in the European province until the Leymeriella regularis Subzone. In southern England and northern France, pre-regularis Subzone tardefurcata Zone sediments contain species of Hypacanthoplites which also occur in the schrammeni and acuticostata Subzones in north Germany, but Leymeriella is absent. Using this occurrence of species of Hypacanthoplites common to north Germany and southern England, Casey (1961) has correlated his Subzone of Farnhamia farnhamensis with that of Leymeriella schrammeni. Unfortunately, the hoplitid genus Farnhamia has not yet been found outside southern England.

Interprovincial correlation of the equivalent of the schrammeni Subzone is also difficult. Among ammonite alternatives which might be considered to be suitable to mark the base of the Albian, and which are geographically more widespread in distribution, none provide as precise a boundary for the Stage as does Leymeriella in the European province. Hypacanthoplites occurs in the Gondwanan province as a rarity, but its species are too long ranging and imprecise to be suitable for use as boundary markers. It does not occur in the Arctic province. To extend the base of the Albian back to the base of the Hypacanthoplites jacobi Zone would not solve the problem of interprovincial correlation. It would involve, also, the placing of the Albian boundary at a non-sequence in most areas outside north Germany, the present boundary stratotype area. Douvilleiceras is a cosmopolitan ammonite genus in the European and Gondwanan provinces. It appears first in the regularis Subzone of the tardefurcata Zone and has a long time range into the early Middle Albian (Lyelliceras lyelli Subzone). Unfortunately, the morpho-species of Douvilleiceras are not sufficiently distinctive to provide a precise base for the Stage which can be recognized easily over a wide area. Because of the presence of Dou- villeiceras, it has been assumed that sediment containing this genus in a number of areas in the Gondwanan province are of Lower Albian, Douvilleiceras mammillatum Zone age. In fact, they can be shown in a number of instances to be of early Middle Albian age.

It would appear to be sensible at present to retain the base of the Albian at the base of the schrammeni Subzone in the well documented European province, and to investigate the occurrence of extra-European province visitors for the purposes of correlation. Much of this investigation still requires to be done, but it is becoming clear that a major sedimentary hiatus affects the late Aptian and at least the early Lower Albian throughout much of the Gondwanan province. The recent discovery of early Albian ammonites in Peary Land, north Greenland (Birkelund \& Håkansson 1983) has largely solved the problem of correlation of the earliest Albian of the European province with that of the Arctic province. Leymeriella trollei Birkelund \& Håkansson indicates a schrammeni Subzone age, although not the earliest part of the Subzone. It is associated with the Arctic genus Freboldiceras. Freboldiceras praesingulare Birkelund \& Håkansson is considered to be slightly earlier in age than $F$. singulare Imlay of the Brewericeras hulenense Zone of Alaska (Imlay 1960). A critical examination of the occurrence of Arcthoplites indicates that it is confined to the Leymeriella acuticostata Subzone (the L. tardefurcata Subzone of eastern European workers). In Peary Land, Birkelund \& Håkansson (1983) report the occurrence of Arcthoplites jachromensis (Nikitin) a few metres above the late schrammeni Subzone fauna. Nagy (1970) records the association of the acuticostata Subzone species Leymeriella germanica Casey with a Freboldiceras - Arcthoplites fauna in southern Spitzbergen.

In terms of the micro-palaeontology of the late Aptian and early Albian, there are no suitable appearances of foraminiferal or nannoplankton species known at present (eg. Hart et al. 1981, Taylor 1982). However, the recent revision of the ostracods of the Protocythere nodigera group by Kemper (1982b) provides a number of species, including $P$. nodigera sensu stricto, which appear close to the base of the Albian as defined by the ammonite fauna. 


\section{The base of the Middle Albian Substage}

The earliest Zone of the Middle Albian in the European (hoplitinid) faunal province, that of Hoplites dentatus, has included since its definition by Casey (1961), the Subzone of Hoplites ('Isohoplites') eodentatus. This Subzone is characterized by ammonites which are morphologically transitional between Pseudosonneratia of the typica group and Hoplites of the dentatus group. It replaced the poorly defined Subzone of $\mathrm{Dou}$ villeiceras inaequinodum of Spath (eg. 1941, 668 ), included by him in the $D$. mammillatum Zone. Subsequent investigation of the ammonite fauna of this Subzone, and the need to be able to define a Substage boundary for the Middle Albian capable of widespread geographical recognition, has suggested the eodentatus Subzone be regarded as latest Lower Albian. Its ammonite fauna is essentially of mammillatum Zone aspect and it is included here in that Zone (and see Owen 1984).

It is fortunate that the eodentatus Subzone, which can be recognized only in the European (hoplitinid) faunal province, has seen invasions of the more cosmopolitan douvilleiceratid and lyelliceratinid ammonites characteristic of the Gondwanan (brancoceratid) faunal province. Among the endemic hoplitinids such as Hoplites ('Isohoplites') eodentatus and its allies, which are closer to Pseudosonneratia and should be included in that genus (Saveliev 1976), species of Otohoplites are common. At the end of the Subzone, the eodentatus group exhibited a relatively sudden change in the arrangement of the ribendings on the ventral-lateral shoulders from the isometric arrangement characteristic of Pseudosonneratia to the en-echelon pattern characteristic of Hoplites sensu stricto. In the hoplitinid faunal province, the base of the overlying Subzone of Lyelliceras lyelli, here regarded as the base of the Middle Albian Substage, can be placed at this relatively sudden and general adoption of the ventral aspect of Hoplites.

Among the more cosmopolitan elements, Douvilleiceras is common in the eodentatus Subzone; it is rare in deposits of Lyelliceras lyelli Subzone age, although it occurs up to the end of that Subzone. The lyelliceratinid genus Tegoceras, which occurs in the mammillatum Zone in the
European province albeit that it is rare, also undergoes a relatively sudden morphological change at the end of the eodentatus Subzone to produce Lyelliceras lyelli and its relatives of the lyelli Subzone. The base of the lyelli Subzone is marked by the occurrence of Lyelliceras pseudolyelli (Parona \& Bonarelli), L. hirsutum (Parona \& Bonarelli) and L. huberianum (Pictet) among other species in both the European and Gondwanan provinces (eg. Owen 1971, Destombes, Juignet \& Rioult 1973, Destombes 1979).

The Subzone of Lyelliceras lyelli is capable of wide geographic recognition in both the hoplitinid and brancoceratid faunal provinces (Owen 1971, 1984) and its base, defined above, is an ideal boundary for the base of the Middle Albian Substage. The best sedimentary and faunal sequence across the boundary is situated in the classic region of the Aube, France, where, a number of sections can provide a regional stratotype (eg. Owen 1971, Destombes 1979). Problems do arise, however, in correlating the Arctic province with the rest of the World at this boundary (Owen 1973). However, in Spitzbergen Pseudosonneratia ('Isohoplites') and early Hoplites sensu stricto are both associated with species of the Arctic genus Grycia including $G$. sablei (Imlay) (Nagy 1970).

In terms of micropalaeontological markers, the base of the lyelli Subzone corresponds to the base of Zone 3(i) of Price (1977 and see Hart et al. 1981). Among nannoplankton species which appear at about this boundary, Prediscosphaera cretacea, Dictyococcites parvidentatus, Gaarderella granulifera and Braarudosphaera regularis might prove useful in the classification of oceanic borehole core sequences (Taylor 1982). In this context, it is worth noting that a Lyelliceras lyelli Subzone ammonite fauna has been described from the Deep Sea Drilling Project boring, Hole 398D, on the Biscay margin (Renz 1979).

\section{The base of the Upper Albian Substage}

A strong case for drawing the lower boundary of the Upper Albian at the appearance of the ammonite Dipoloceras cristatum (Brongniart), and contemporary species of Dipoloceras, was made 
by Breistroffer (1947). With few exceptions, this practice has been followed by subsequent workers. Dipoloceras cristatum and its close relatives are of widespread geographical distribution in both the European and Gondwanan provinces and provide, therefore, an easily recognized marker for the purposes of correlation. In the European (hoplitinid) province, the appearance of this group coincides with the start of a general colonisation by the brancoceratinid, mojsisovicsiinid and mortoniceratinid ammonites of the Gondwanan province, which co-existed with the endemic hoplitinids throughout the remainder of the Albian. In a few areas of the European province (eg. Transcaspia in the Soviet Union) Dipoloceras has not yet been found, but species of Semenovites which occur also in the cristatum Subzone of western Europe are well represented and permit a direct correlation to be made (Owen 1984).

A marine link between the European (hoplitinid) and Arctic (gastroplitid) faunal provinces existed for a short interval of time in the early Upper Albian (Owen 1973, Jeletzky 1980). Pseudogastroplites, an Arctic province ammonite genus, is represented by a unique specimen of $P$. cantianus (Spath) in Bed VIII of the Gault at Folkestone, Kent, south east England. The correlation of the Arctic province ammonite sequence with that of Europe given by Jeletzky $(1980,20)$ is not based on firm evidence. The possibility of a sequence of Pseudogastroplites faunas, as advocated by Jeletzky, of which $P$. arcticus Jeletzky is the last and might be the equivalent of the cristatum Subzone of Europe, needs further investigation.

The ammonite occurrences can be supplemented by the relatively rapid change in morphology shown in the bivalve genus Birostrina. At the base of the cristatum Subzone in the littlecondensed clay sequences at Wissant, north east France, and Folkestone, south east England, Birostrina concentrica (Parkinson), the abundant concentrically-ribbed form of Middle Albian deposits, changes into the radially-ribbed form $B$. sulcata (Parkinson) by means of a short-lived intermediate stage called B. 'subsulcata' (Wiltshire). B. sulcata reverts back into the concentrica form, again by means of a subsulcata stage, by the beginning of the Hysteroceras varicosum Subzone. Comparisons with the ammonite faunas show that these changes are synchronous events wherever Birostrina is found.

The section at Folkestone, Kent, is selected here as the stratotype of the Middle Albian Upper Albian boundary within the hoplitinid province. It can be argued that the basal part of Bed VIII of the Gault of Folkestone is a condensed phosphatic pebble horizon produced by a period of current scour associated with tectonic disturbance in the early part of the cristatum Subzone. However, this condensation is not extensive and both at Folkestone and in borings nearby, the lower part of Bed VIII is represented by a thin clay sequence in which the vertical change from $B$. concentrica to $B$. sulcata, mentioned above, is seen to occur. At Folkestone, these earliest cristatum Subzone sediments are preceded by sediments of Anahoplites daviesi Subzone age which yield ammonites of the Anahoplites rossicus Subzone (sensu Saveliev 1981) of the Soviet Union (Owen 1984). Although a more complete sequence of clays of earliest cristatum Subzone age is present at Wissant, on the opposite side of the Channel from Folkestone, daviesi Subzone sediments are absent (Owen 1971). Within the broad Gondwanan faunal province, the best known sequence across the Middle Albian - Upper Albian boundary is situated in Tarrant County, Texas, in the United States (eg. Young 1966) where the cristatum Subzone is represented within the Goodland Limestone.

No precise foraminiferal or nannofossil Zone boundaries coincide with the base of the cristatum Subzone (eg. Price 1977, Taylor 1982). However, Tranolithus salillum appears at, or near, the base of the cristatum Subzone and might prove a useful marker fossil.

\section{Summary}

At the Symposium on Cretaceous Stage Boundaries held in Copenhagen in October 1983, the following recommendations were made concerning the Albian.

1. The lower boundary of the Albian Stage be placed at the base of the Subzone of Leymeriella schrammeni with a stratotype section at Vöhrum in the Hannover-Braun- 
schweig region of north Germany (Owen 1979).

2. The lower boundary of the Middle Albian Substage be placed at the base of the Lyelliceras lyelli Subzone which also corresponds with the base of the foraminiferal Zone 3(i) of Price, the stratotype section being in the Aube, France.

\section{The lower boundary of the Upper Albian Sub-} stage be placed at the base of the Dipoloceras cristatum Subzone with a stratotype section at Folkestone, Kent, England. This boundary coincides with the morphological change in the bivalves from Birostrina concentrica (Parkinson) to Birostrina sulcata (Parkinson). It is possible that the nannoplankton species Tranolithus salillum appears at this level.

Acknowledgements. My thanks are due to Professor Tove Birkelund (Copenhagen) and to Dr J. A. Jeletzky (Geological Survey of Canada) for useful discussion of Greenland and Canadian Arctic ammonite faunas, and to Dr E. Kemper (Bundesanstalt für Geowissenschaften und Rohstoffe, Hannover) for discussion on the Albian lower boundary in north Germany.

\section{Dansk sammendrag}

Etagen albiens nedre grænse defineres på grundlag af første optraden af Leymeriella schrammeni og en grænse stratotype foreslås i Nordtyskland. Denne grænse kan korreleres med den arktiske provins, men endnu ikke med Gondwana provinsen. På grund af etagens lange varighed (14-15,5 mill. år) anbefales det at definere nedre, mellem og øvre albien formelt. Mellem og øvre albien foreslås defineret på grundlag af henholdsvis første optræden af Lyelliceras lyelli og Dipoloceras cristatum.

\section{References}

Birkelund, T. \& Håkansson, E. 1983: The Cretaceous of North Greenland - a stratigraphic and biogeographical analysis. Zitteliana 10, 7-25, pls 1-3.

Breistroffer, M. 1947: Sur Les Zones d'Ammonites dans l'Albien de France et d'Angleterre. Trav. Lab. Géol. Univ. Grenoble 26, 17-104.

Brinkmann, R. 1937: Biostratigraphie des Leymeriellenstammes nebst Bemerkungen zur Paläogeographie des nordwestdeutschen Alb. Mitt. Geol. Staatsinst. Hamb. 16, 1-18.

Casey, R. 1957: The Cretaceous Ammonite genus Leymeriella, with a systematic account of its British occurrences. Palaeontology 1, 28-59, pls 7-10.

Casey, R. 1960 - : A Monograph of the Ammonidea of the Lower Greensand. Palaeontogr. Soc. (Monogr.) Pts I-IX, i-xxxvi \& 1-660, pls I-CXII (not yet completed).
Casey, R. 1961: The stratigraphical palae ontology of the Lower Greensand. Palaeontology 3, 487-621, 8 pls.

Destombes, P. 1979: Les Ammonites de l'Albien inférieur et moyen dans le stratotype de l'Albien: Gisements, Paléontologie, Biozonation. In L'Albien de l'Aube. Les Stratotypes Français 5, 51-194, pls 4.1-4.27. Editions du CNRS.

Destombes, P., Juignet, P. \& Rioult, M. 1973: Ammonites de l'Aptien-Albien di Bec du Caux, Normandie (N. W. France). Bull. Soc. gếol. Normandie 61, 49-106, pls I-V.

Harland, W. B., Cox, A. V., Llewellyn, P. G., Pickton, C. A. G., Smith, A. G. \& Walters, R. 1982: A geologic time scale. Cambridge University Press i-xii, 1-131.

Hart, M. B., Bailey, H. W., Fletcher, B., Price, R. \& Sweicicki, A. 1981: Cretaceous. In Jenkins, D. G. \& Murray, J. W. (eds.) Stratigraphical Atlas of Fossil Foraminifera. Ellis Horwood 149-227.

Imlay, R. W. 1959: New genera of early Cretaceous (Albian) ammonites from Alaska. J. Paleont. 33, 179-185, pls 2930.

Imlay, R. W. 1960: Early Cretaceous (Albian) ammonites from the Chitina Valley and Talkeetna Mountains, Alaska. U.S. geol. Surv. Prof. Pap. 354D, 87-114, pls 11-19.

Jeletzky, J. A. 1980: New or formerly poorly known, biochronologically important gastroplitinid and cleoniceratinid (Ammonitida) taxa from middle Albian rocks of midwestern and Arctic Canada. Geol. Surv. Pap. Can. 79-22, i-viii, 1-62, pls 1-10.

Jones, D. L. \& Grantz, A. 1967: Cretaceous ammonites from the lower part of the Matanuska Formation southern Alaska. U.S. geol. Surv. Prof. Pap. 547, 1-49, pls 1-10.

Kemper, E. 1975: Die Cephalopoden aus dem Unter-Alb (Zone der Leymeriella tardefurcata) von Altwarmbüchen. Ber. nathist. Ges. 119, 87-111.

Kemper, E. 1982a: (ed.) Das späte Apt und frühe Alb Nordwestdeutschlands. Geol. $\mathrm{Jb}$. A65, 1-703.

Kemper, E. 1982b: 7. Die Mikrofossilien des späten Apt und frühen Alb in Nordwestdeutschland. 7.1. Die Ostrakoden des Apt und frühen Alb des Niedersächsischen Beckens. Geol. Jb. A65, 413-439, pls 7.1.1-7.1.6.

Nagy, J. 1970: Ammonite faunas and stratigraphy of the Lower Cretaceous (Albian) rocks in southern Spitzbergen. $S k r$. norsk. Polarinst. 152, 1-58, 12 pls.

Odin, G. S. 1982: Numerical dating in Stratigraphy. 2 vols. Wiley Interscience, $1094 \mathrm{pp}$.

Owen, H. G. 1971: Middle Albian Stratigraphy in the AngloParis Basin. Bull. Brit. Mus. nat. Hist. (Geology). Suppl. $8,164 \mathrm{pp}, 3$ pls.

Owen, H. G. 1973: Ammonite faunal provinces in the Middle and Upper Albian and their palaeogeographical significance. In Casey, R. \& Rawson, P. F. (eds.): The Boreal Lower Cretaceous. Geol. J. Spec. Issue 5, 145-154.

Owen, H. G. 1976: The stratigraphy of the Gault and Upper Greensand of the Weald. Proc. geol. Assoc. 86, 475-498.

Owen, H. G. 1979: Ammonite Zonal Stratigraphy in the Albian of North Germany and its setting in the Hoplitinid Faunal Province. In Wiedmann, J. (ed.) Aspekte der Kreide Europas. I. U. G. S. Series A, 6, 563-588.

Owen, H. G. 1984: The Albian Stage: European province chronology and ammonite zonation. Cret. Res. 5.

Price, R. J. 1977: The stratigraphical zonation of the Albian sediments of north-west Europe, as based on foraminifera. Proc. Geol. Ass. 88, 65-91.

Renz, O. 1979: 7. Lower Cretaceous Ammonoidea from the northern Atlantic, Leg 47B, Hole 398D, DSDP. Initial Rep. deep Sea Drilling Proj. 47(2), 361-369, pls 1-2.

Saveliev, A. A. 1973: Stratigrafiya i Ammonitỹ nizhnego Al'ba Mangyshlaka (zonȳ Leymeriella tardefurcata i Leymeriello regularis). Trudy yses. neft. nauchno-issled. geol.-rasv. Inst. 323, 1-339, pls 1-XLIV. 
Saveliev, A. A. 1974: Novaya zonal'naya schema stratigrafii nizhnego Al'ba Mangyshlaka. Trudȳ vses. neft. nauchnoissled. geol.-rasv. Inst. 350, 116-122.

Saveliev, A. A. 1976: Novaya zonal'naya schema stratigrafii srednego Al'ba Mangyshlaka. Trudy' vses. neft. nauchnoissled. geol.-rasv. Inst. 388, 119-129, pl. 1.

Saveliev, A. A. 1981: O zonal'nom delenii Al'bskogo yarusa Mangyshlaka po ammonitam. In Naidin, D. P. \& Krasilov, V. A. (eds.) Evolyutsiya organizmov i biostratigrafiya serediny melovogo perioda. Akademiya Nauk SSR Dal'nevostochnȳi nauchnȳi tsentr biologo-pochvennȳi Institut, Vladivostok. 41-46.
Spath, L. F. 1923-43: A Monograph of the Ammonoidea of the Gault. Palaeontogr. Soc. (Monogr.) 2 vols, 787 pp, 72 pls.

Taylor, R. J. 1982: Lower Cretaceous (Ryazanian to Albian) calcareous nannofossils. In Lord, A. R. (ed) A Stratigraphical Index of Calcareous Nannofossils. Ellis Horwood, 40-80, pls 4.1-4.8. Tables 4.1-4.2.

Young, K. 1966: Texas Mojsisovicziinae (Ammonoidea) and the Zonation of the Fredericksburg. Mem. geol. Soc. Am. 100, i-viii, 1-225, pls 1-38. 